\title{
PENGARUH KUALITAS PRODUK, HARGA DAN STORE ATMOSPHERETERHADAP MINAT BELI KONSUMEN PADA TOKO EMAS DAN MUTIARA DISEKARBELA KOTA MATARAM
}

\author{
Yusi Faizathul Octavia \\ Rahman Dayani
}

\begin{abstract}
This study aimed to analyze the significant influence between product quality, price, and store atmosphere toward consumer purchase intention on the gold and pearl store in Sekarbela Mataram city. Intake of respondents conducted with convenience sampling technique using a questionnaire distributed to 100 respondents. The data analysis technique used is multiple linear regression analysis. Based on the analysis conducted, it can be concluded that the variable quality of the product, price, and store atmosphere positive and significant impact toward consumer purchase intention on the gold and pearl store in Sekarbela Mataram city. This means that if the quality of the product, price, and store atmosphere is enhanced by the gold and pearls shop owners in Sekarbela city of Mataram, can be increasing the consumer purchase intention. While the dominant variable affecting consumer purchase intention is the store atmosphere variable.
\end{abstract}

Keywords:Quality of Product, Price, Store Atmosphere and Purchase Intention.

\section{Pendahuluan}

Harapan yang dimiliki seorang konsumen belum tentu akan mendorong konsumen yang bersangkutan untuk melakukan pembelian. Harapan tersebut harus mampu distimulir sehingga timbulnya tekanan untuk segera mewujudkannya dalam bentuk tindakan pembelian. Terdapat bermacam faktor yang dapat menjadi stimulus antara lain adalah, produk yang ditawarkan, harga produk dan juga store atmosphere. Dengan kata lain, faktor-faktor tersebut bisa mempengaruhi perasaan atau mood dari para konsumen yang berkunjung ke toko milik perusahaan sehingga berminat untuk melakukan pembelian.

Begitu juga halnya dengan yang terjadi pada toko perhiasan emas dan mutiara di Sekarbela, yang merupakan salah satu bentuk usaha yang bergerak di bidang distribusi perhiasan di Kota Mataram.Setiap toko perhiasan emas dan mutiara menetapkan kebijakan harga jual produk relatif terjangkau oleh konsumen, dimana harga untuk setiap produk bervariasi tergantung dari jenis produk. Produk yang dihasilkan oleh sentra kerajinan emas dan mutiara di daerah Sekarbela tergolong ke dalam produk yang bermutu tinggi. Hal ini dapat dibuktikan jika dilihat dari segi produk perhiasan emas yang baik dimana warna emas kuning kemerahan, mengkilat serta tidak mudah pudar kilatnya, awet dalam pemakaiannya meskipun dipakai setiap hari. Sedangkan untuk perhiasan emas yang memiliki kualitas kurang baik ciri-cirinya yaitu warna perhiasan emas kuning sekali, sedikit buram dan kurang bercahaya, serta pemakaiannya tidak tahan lama.

Harga perhiasan emas per gram yaitu sebesar Rp. 442.750 untuk emas 22 karat dan Rp. 538.000 untuk emas 24 karat (www.logammulia.com diakses tanggal 12 Juli 
2014). Untuk produk mutiara dibedakan atas warna kulit dan cahaya atau kilau yang ditimbulkan. Jenis mutiara yang diproduksi dan dipasarkan dibedakan menjadi tiga. Mulai dari kualitas mutiara yang paling baik adalah mutiara grade $\mathrm{A}$ dengan harga Rp. 500.000, grade B dengan harga Rp. 400.000 dan yang terakhir adalah mutiara grade $C$ dengan harga Rp. 250.000.

Produk perhiasan emas dan mutiara yang dihasilkan berupa satu set perhiasan yang terdiri dari (kalung, gelang, cincin dan anting), satu set stainless yang terdiri dari (kalung, gelang, cincin dan anting), anting-anting, kalung mutiara, cincin, bros dan liontin mutiara. Ciri khas utama produk yang dihasilkan adalah bahan baku yang digunakan merupakan bahan baku yang berkualitas tinggi. Masing-masing toko perhiasan emas dan mutiara di Sekarbela menetapkan sendiri harga produknya, dimana harga untuk setiap produk bervariasi tergantung dari jenis dan model produk. Selain itu toko perhiasan emas dan mutiara di Sekarbela memberikan diskon kuantitas, yaitu memberikan potongan harga kepada konsumen.

Nama Sekarbela sudah sangat terkenal dikalangan penyuka perhiasan mutiara dan wisatawan yang berkunjung ke pulau Lombok. Daerah Sekarbela ini jaraknya tidak jauh dari pusat kota Mataram, hanya $4 \mathrm{~km}$. Toko-toko perhiasan emas dan mutiara itu berjajar di sepanjang jalan Sultan Kaharudin. Di sini konsumen dapat memilih perhiasan sesuai selera, ada gelang, kalung, anting, assesoris baju dan lain-lain dengan kualitas kelas satu. Semuanya serba mutiara, baik yang dipadu dengan emas maupun perak. Storefront design atau desain luar toko perhiasan emas dan mutiara di Sekarbela terlihat tampak jelas, masing-masing toko menjadi mudah dikenali dan mudah diingat karena memiliki papan nama yang terpampang jelas di luar toko. Desain luar toko di sini sudah dengan sangat jelas mengidentifikasikan nama dan gambaran umum tentang toko mereka yang memberi petunjuk bahwa perhiasan emas dan mutiara tersedia di dalamnya.

Desain interior toko perhiasan emas dan mutiara di Sekarbela rata-rata menggunakan lantai yang polos dan. Hal ini tentunya akan menimbulkan kesan biasa dan murah. Untuk dinding, setiap toko perhiasan menggunakan dinding yang yang di cat, ada juga sebagian toko melapisi dindingnya dengan wallpaper atau menggunakan berbagai macam pilihan paneling atau hiasan dinding. Untuk plafon, dimana setiap toko menggunakan plafon biasa, sehingga menimbulkan kesan ekonomis tetapi tidak istimewa. Untuk penerangan seringkali luput dari perhatian pemilik toko perhiasan, padahal penerangan dapat meningkatkan penjualan. Store design yang efektif harus dapat dirasakan oleh semua panca indera, mulai dari indera penglihatan, pendengaran, penciuman, dan peraba atau sentuhan. Setiap pemilik toko perhiasan emas dan mutiara di Sekarbela dapat menggunakan hal ini untuk menciptakan suatu mood di dalam toko bagi konsumen.

Berdasarkan pada fenomena di atas maka tujuan dari penelitian ini adalah untuk mengetahui pengaruh kualitas produk, harga, dan store atmosphere terhadap minat beli konsumen pada toko emas dan mutiara di Sekarbela kota Mataram. Elemen-elemen yang dianalisis dalam penelitian ini berdasarkan pendapat Berman 
dan Evans (2001) yaitu mencakup kualitas produk, harga, dan store atmosphere (store exterior, general interior, store layout, dan interior display).

Berdasarkan pada latar belakang di atas, maka perumusan masalah yang bisa diajukan dalam penelitian ini yaitu, apakah Product Knowledge yang terdiri dari Kegunaan Layanan Kesehatan, Kemudahan Menggunakan Layanan Kesehatan, dan Pergaulan Sosial berpengaruh signifikan terhadapMinat Menggunakan Layanan Kesehatan, serta variabel manakah yang dominan mempengaruhiMinat Menggunakan Layanan Kesehatan pada RS Jiwa Provinsi NTB?

Berdasarkan uraian latar belakang diatas maka dapat dirumuskan permasalahan apakah variabel kualitas produk, harga, dan store atmosphere berpengaruh signifikan terhadap minat beli konsumen, serta manakah diantara variabel kualitas produk, harga, dan store atmosphere yang berpengaruh dominan terhadap minat beli konsumen pada toko emas dan mutiara di Sekarbela kota Mataram?

\section{Tinjauan Teori}

Produk (Product)

Definisi produk menurut Stanton(2005:139) adalah seperangkat atribut baik berwujud maupun tidak berwujud, termasuk di dalamnya masalah warna, harga, nama baik pabrik, nama baik toko yang menjual (pengecer), dan pelayanan pabrik serta pelayanan pengecer, yang diterimaoleh pembeli guna memuaskan keinginannya.Menurut KotlerdanArmstrong(2006:337) produk adalah semua yang dapat ditawarkan kepada pasar untuk diperhatikan, dimiliki, digunakan, atau dikonsumsi yang dapat memuaskan keinginan atau kebutuhan pemakainya.Peter dan Olson (2000:67) menjelaskan bahwa konsumen dapat memiliki tiga jenis pengetahuan tentang produk yaitu pengetahuan tentang ciri atau karakteristik produk, konsekuensi atau manfaat positif menggunakan produk dan nilai yang akan dipuaskan oleh produk tersebut.

Berdasarkan definisi di atas maka dapat ditarik kesimpulan bahwa produk adalah segala sesuatu yang dapat ditawarkan kepada konsumen untuk dapat dimiliki, digunakan, atau dikonsumsi sehingga dapat memuaskan keinginan dan kebutuhan konsumen melalui ciri-ciri yang dimiliki baik yang nyata maupun yang tidak nyata. Sebab konsumen hanya terus menggunakan produk itu selama produk tersebut mampu memuaskan kebutuhan dan keinginan, sehingga perencanaan pemasaran harus lebih berorientasi pada konsumen dengan menyediakan dan menawarkan produk yang dapat memberi manfaat pemuas kebutuhan dan keinginan mereka. Produk-produk yang dipasarkan meliputi barang fisik, jasa, pengalaman, acara-acara, tempat, properti, organisasi dan gagasan. Jadi produk dapat berupa manfaat tangible maupun intangible yang dapat memuaskan konsumen.

\section{Harga (Price)}

Saladin (2002:95) mendefinisikan harga sebagai sejumlah uang atau alat tukar untuk memperoleh produk atau jasa.Alma (2006:169) mendefinisikan harga sebagai 
nilai suatu barang yang dinyatakan dengan uang. Adapun pengertian harga menurutSimamora (2000:574) dalam bukunya yaitu harga adalah jumlah uang yang dibebankan atau dikenakan atas sebuah produk atau jasa. Penentuan harga merupakan titik kritis dalam bauran pemasaran karena harga menentukan pendapatan dari suatu usaha/bisnis. Keputusan harga juga sangat signifikan di dalam penentuan nilai/manfaat yang dapat diberikan kepada pelanggan dan memainkan peranan penting dalam gambaran kualitas jasa. Menurut Lamb et al., (2001:268) harga adalah apa yang harus diberikan oleh konsumen (pembeli) untuk mendapatkan suatu produk. Sementara menurut Pepadri (2002) harga adalah sejumlah uang yang ditentukan perusahaan sebagai imbalan barang atau jasa yang diperdagangkan dan sesuatu yang lain yang diadakan perusahaan untuk memuaskan keinginan konsumen. Harga sering merupakan elemen yang paling fleksibel di antara keempat elemen bauran pemasaran.Dari beberapa definisi di atas maka dapat disimpulakn bahwa harga merupakan sejumlah uang yang diperlukan untuk mendapatkan sejumlah kombinasi dari barang maupun jasa beserta pelayanannya.

\section{Store Atmosphere}

Pengertian store atmosphere menurut Berman dan Evan (2007:454) yaitu: "Atmosphere refers to the store's physical characteristics that project an image and draw customer". Pernyataan tersebut bermakna bahwa suasana mengacu pada karakteristik fisik toko yang memproyeksikan gambar dan menarik pelanggan. Berman dan Evans (2007) membagi elemen-elemen store atmosphere ke dalam empat elemen, yaitu store exterior, general interior, store layout dan interior display.Menurut Kotler dan Keller (2006:146) "suasana toko (store atmosphere) adalah suasana terencana yang sesuai dengan pasar sasarannya dan yang dapat menarik pelanggan untuk membeli". Kotler dan Keller (2006) menambahkan bahwa proses penciptaan store atmosphere adalah kegiatan merancang lingkungan pembelian dalam suatu toko dengan menentukan karakteristik toko tersebut melalui pengaturan dan pemilihan fasilitas fisik toko dan aktifitas barang dagangan. Lingkungan pembelian yang terbentuk, melalui komunikasi visual, pencahayaan, warna, musik dan wangiwangian, tersebut dirancang untuk menghasilkan pengaruh atau respon emosional dan persepsi khusus dalam diri konsumen sehingga bersedia melakukan pembelian serta kemungkinan meningkatkan pembeliannya.

Dari pengertian di atas, dapat diketahui bahwa store atmosphere adalah suatu karakteristik fisik dan sangat penting bagi setiap bisnis ritel hal ini berperan sebagai penciptaan suasana yang nyaman untuk konsumen dan membuat konsumen ingin berlama-lama berada di dalam toko dan secara tidak langsung merangsang konsumen untuk melakukan pembelian. Store atmosphere tersebut meliputi hal-hal yang bersifat luas seperti halnya store exterior, general interior, store layout dan interior display.

\section{Minat Beli Konsumen}


Minat beli (niat beli) merupakan keinginan yang muncul dalam diri konsumen terhadap suatu produk sebagai dampak dari suatu proses pengamatan dan pembelajaran konsumen atau individu tersebut terhadap suatu produk. Durianto (2003:58), mengungkapkan bahwa minat beli adalah keinginan untuk memiliki produk, minat beli akan timbul apabila seseorang konsumen sudah terpengaruh terhadap mutu dan kualitas dari suatu produk, informasi seputar produk, contohnya harga, cara membeli dan kelemahan serta keunggulan produk dibanding merek lain.Menurut Fishbein dan Ajzen (2004:197), intention (minat) adalah sebuah rencana atas sepertinya seseorang akan berperilaku dari situasi tertentu dengan cara-cara tertentu baik seseorang akan melakukannya atau tidak. Sementara itu menurut Peter dan Olson (1999:149), intention adalah sebuah rencana untuk terlibat dalam suatu perilaku khusus guna mencapai tujuan.

Berdasarkan pendapat tersebut dapat disimpulkan bahwa minat beli timbul karena adanya ketertarikan dari individu tersebut terhadap produk yang diamati dan diiringi dengan kemampuan untuk membeli produk tersebut. Selain itu produk yang telah diamati dan dipelajari tersebut juga akan lebih mudah untuk diperoleh. Minat beli didefinisikan sebagai kemauan untuk membeli calon-calon pembeli yang masih merupakan pembeli potensial atas suatu produk yang sesuai dengan yang diinginkan. Konsumen yang masih pembeli potensial ini akan menjadi pembelian efektif maka perusahaan harus melakukan berbagai pendekatan, mengingatkan serta menjelaskan daya dan fungsi produk kepada calon pembeli.

Hubungan antar Konsep Produk, Harga, dan Store Atmosphere terhadap Minat Beli

Menurut Kotler (2006) faktor-faktor yang mempengaruhi minat beli konsumen pada dasarnya adalah produk yang merupakan satu ikatan jasa yang disediakan untuk memuaskan kebutuhan konsumen. Berbagai atribut yang melekat pada produk hanya akan menghasilkan value jika atribut tersebut menghasilkan manfaat bagi konsumen. Oleh karena itu, maka value yang dihasilkan oleh suatu produk dimulai sejak saat pelanggan berusaha mencari produk sampai saat pelanggan menghentikan pemakaian produk.

Selain produk, yang termasuk ke dalam faktor-faktor yang mempengaruhi minat beli adalah harga (Kotler, 2006). Harga merupakan salah satu keputusan yang penting bagi manajemen. Harga yang ditetapkan harus dapat menutup semua ongkos dan dapat menghasilkan laba. Prinsipnya dalam penentuan harga ini adalah menitikberatkan pada kemauan pembeli untuk harga yang telah ditentukan dengan jumlah yang cukup untuk menutup ongkos-ongkos dan menghasilkan laba.

Cooper (1981) mengatakan bahwa atmosfer toko yang memiliki keindahan akan membentuk citra positif di benak konsumen terhadap toko tersebut, dan jika hal tersebut berlangsung lama maka kecenderungan konsumen untuk memilih toko tersebut sangat tinggi. Sebuah toko yang memiliki atmosfer, seperti toko yang memiliki kepribadian dan hal ini yang dapat menjadikan atmosfer tersebut sebagai alat komunikasi sebuah toko kepada konsumen.

Berdasarkan penjelasan tersebut, bisa dipahami bahwa terdapat hubungan antara kualitas produk, harga, dan store atmosphere dengan minat beli, karena ketiga 
variabel tersebut dapat mempengaruhi minat beli konsumen. Untuk itu, dipahami bahwa antara konsep kualitas produk, harga, store atmosphere dan minat beli konsumen saling berkorelasi karena diantara setiap variabel ini saling mempengaruhi hingga mampu membentuk sebuah minat beli oleh konsumen.

Adapun model kerangka konseptual dalam penelitian ini digambarkan sebagai berikut:

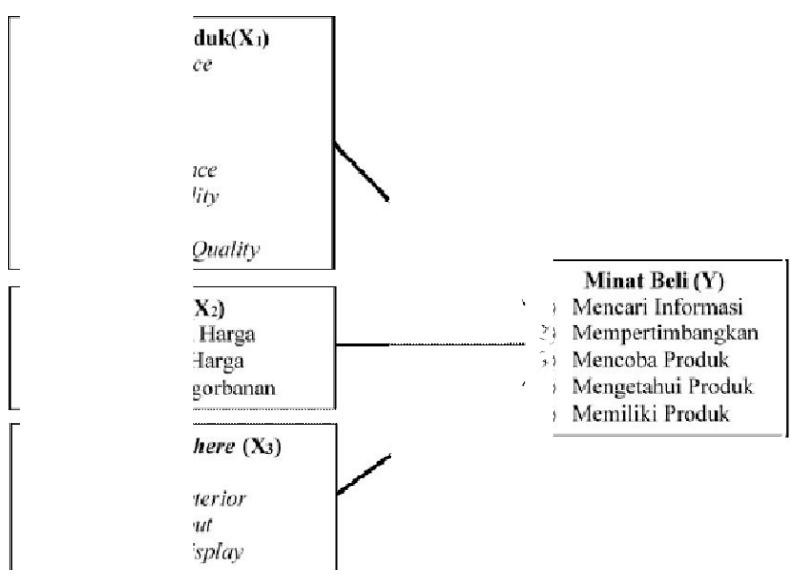

\section{Gambar Kerangka Konseptual Penelitian}

Berdasarkan latar belakang dan perumusan masalah dapat dirumuskan hipotesa sebagai berikut:

a) Diduga bahwa faktor kualitas produk, harga, dan store atmosphere berpengaruh signifikan terhadap minat beli konsumen pada toko emas dan mutiara di Sekarbela kota Mataram.

b) Diduga bahwa diantara variabel kualitas produk, harga, dan store atmosphere yang berpengaruh dominan terhadap minat beli konsumen pada toko emas dan mutiara di Sekarbela kota Mataram adalah variabel store atmosphere.

\section{Metode Penelitian}

Penelitian ini termasuk penelitian asosiatif, karena bersifat menerangkan dan bertujuan menguji hipotesis tentang adanya hubungan sebab akibat antar berbagai variabel yang diteliti, dalam hal ini melihat pengaruh variabel kualitas produk, harga dan store atmosphere terhadap minat beli konsumen pada toko emas dan mutiara di Sekarbela Kota Mataram.

Populasi dalam penelitian ini adalah seluruh konsumen yang datang ke toko emas dan mutiara di Sekarbela kota Mataram, dimana jumlahnya tidak diketahui secara pasti. Sampel menurut Malhotra (2007) adalah sebagian dari populasi dimaksud yang akan diteliti. Metode sampling yang digunakan dalam penelitian adalah non probability sampling dengan teknik convenience sampling yang merupakan sebuah teknik sampling non probabilitas guna mendapatkan sampel dari elemen yang tepat (Malhotra, 2007). Karena 


\begin{tabular}{cc}
\hline JURNAL MAGISTER MANAJEMEN \\
UNIVERSITAS MATARAM \\
UNRAM
\end{tabular}

jumlah populasi yang diambil berukuran besar dan jumlahnya tidak diketahui secara pasti, sehingga peneliti menentukan jumlah sampel sebanyak 100 responden berdasarkan acuan pada teori yang dikemukakan oleh Roscoe (1975) dalam Sekaran (2006).

Analisis data yang akan dilakukan untuk mengkualifikasikan data kuantitatif atau data yang dapat dihitung adalah dengan menggunakan skala Likert. Selanjutnya dilakukan uji validitas dan reliabilitas yang dimaksudkan untuk menyatakan sejauh mana data yang tertampung pada suatu kuesioner akan mengukur apa yang akan diukur, serta mengetahui konsistensi dan stabilitas hasil skala pengukuran yang digunakan.Sebelum dilakukan pengujian hipotesis, terlebih dahulu dilakukan evaluasi terhadap kemungkinan pelanggaran asumsi klasik regresi, antara lainuji multikolinearitas, uji heteroskedastisitas, dan uji autokorelasi. Adapun penggunaan analisis regresi berganda bertujuan untuk menghitung besarnya pengaruh secara kuantitatif dari suatu perubahan kejadian variabel kualitas produk, harga, dan store atmosphere terhadap kejadian variabel minat beli konsumen.

\section{Analisis Data dan Pembahasan}

Penelitian ini menggunakan pendapat wisatawan lokal sejumlah 100orang yang berbelanja pada toko perhiasan emas dan mutiara di Sekarbela kota Mataram selama periode penelitian. Hasil pengisian kuesioner menunjukkan terdapat beberapa karakteristik responden antara lain, berdasarkan pada kelompok jenis kelamin,umur, pekerjaan, tingkat pendidikan, dan penghasilan per bulan.

Berdasarkan jenis kelamin, dari 100 orang responden, teridentifikasi bahwa sebagian besar responden adalah laki-laki yaitu sebanyak 53 persen dan sisanya adalah perempuan sebanyak 47 persen. Dengan demikian mayoritas responden dalam penelitian ini adalah laki-laki. Dengan perbedaan tersebut menunjukkan bahwa lebih banyak laki-laki yang mengunjungi toko perhiasan emas dan mutiara di Sekarbela kota Mataram dibanding perempuan. Hal ini dikarenakan peluang didapatkannya responden laki-laki lebih besar dibandingkan dengan responden perempuan berdasarkan teknik penarikan sampel convenience yang peneliti gunakan. Bila dikaitkan dengan aktivitas pembelian, peranan pengambilan keputusan di dalam anggota keluarga umunya berada di tangan kepala keluarga atau sumber finansial sebuah keluarga (Ayah/Bapak). Itu sebabnya mayoritas responden berjenis kelamin laki-laki. Laki-laki lebih cepat merasakan suasana toko dan senang melakukan kegiatan berbelanja walau hanya window shopping (melihat-lihat saja tapi tidak membeli). Maka dari itu peneliti lebih banyak dapat menjaring responden laki-laki dibanding perempuan. Selain itu, toko perhiasan emas dan mutiara di Sekarbela kota Mataram menyediakan lebih banyak model perhiasan yang bias dijadikan sebagai pernak-pernik atau oleh-oleh yang merupakan khas pulau Lombok. Banyak para pelancong sengaja membeli perhiasan hanya sebagai oleh-oleh dan cinderamata bagi keluarganya. Sementara itu bagi para perempuan, mereka selalu ingin tampil cantik dan menarik dengan berbagai cara salah satunya melalui barang-barang yang digunakan ditubuhnya salah satunya perhiasan seperti kalung, anting, cincin, dan gelang. Atas dasar inilah peneliti dapat menjaring responden perempuan yang jumlahnya juga cukup banyak. 
Menurut kelompok umur, lebih banyak responden dari kelompok umur 41 sampai dengan 50 tahun sebanyak 36 persen, disusul umur 31 sampai 40 tahun sebanyak 27 persen, kelompok umur di atas 50 tahun sejumlah 20 persen, dan yang paling sedikit adalah kelompok umur di bawah 31 tahun sejumlah 17 persen. Berdasarkan hasil yang diperoleh tersebut terlihat bahwa mayoritas responden berusia antara 41 hingga 50 tahun. Bila dikaitkan dengan tahapan dalam siklus hidup, pada usia antara 41 hingga 50 tahun tersebut konsumen sudah berkeluarga dan memiliki anak atau bahkan cucu, sehingga mereka cenderung akan membeli perhiasan emas dan mutiara sebagai oleh-oleh atau cinderamata bagi anggota keluarganya. Untuk responden yang berusia 21 sampai 30 tahun jumlahnya sangat kecil. Kelangkaan dari terjaringnya responden usia muda disebabkan antara lain pada usia tersebut prioritas pemenuhan kebutuhan konsumen fokus pada hal-hal yang dianggap penting. Responden usia muda yang terjaring menjadi responden disebabkan karena mereka rata-rata membeli perhiasan emas dan mutiara karena pesanan dan titipan dari orang tua mereka, bukan untuk digunakan pribadi.

Hasil penelitian menurut jenis pekerjaan, diketahui bahwa jenis pekerjaan responden terbanyak adalah pegawai swasta yaitu sebanyak 46 persen, disusul dengan wiraswasta sebanyak 33 persen, kemudian PNS sebanyak 12 persen, dan yang paling sedikit adalah mahasiswa sebanyak 9 persen. Bila dikaitkan dengan kelas sosial, mayoritas konsumen merupakan masyarakat kelas menengah yakni pekerja yang berpenghasilan sedang yang sesuai dengan target market produk perhiasan emas dan mutiara. Data ini juga didukung oleh jumlah penghasilan per bulan responden, paling banyak adalah Rp. 5.000.000 - Rp. 10.000.000 yaitu 56 persen, diikuti oleh penghasilan $>\mathrm{Rp} 10.000 .000$ sebanyak 24 persen, dan yang terakhir dengan penghasilan per bulan $<$ Rp. 5.000 .000 sebanyak 20 persen. Tingginya pengelompokkan jumlah penghasilan per bulan responden oleh peneliti, dikarenakan toko perhiasan emas dan mutiara di Sekarbela kota Mataram menyasar kelas menegah ke atas. Banyak responden kelas menengah ke atas ini juga disebabkan pertumbuhan kelas menengah Indonesia yang mengalami pertumbuhan hampir tiga kali lipat dari 7,5 juta jiwa sekarang menjadi 22 juta jiwa (Marketeers edisi Desember 2011).

Berdasarkan tingkat pendidikan, didominasi oleh perguruan tinggi (S1) sebanyak 66 persen, kemudian disusul oleh SMA sejumlah 24 persen dan yang terakhir Pascasarjana sejumlah 10 persen. Hal ini berarti bahwa produk perhiasan emas dan mutiara yang ditawarkan pada toko-toko di Sekarbela kota Mataram, merupakan produk yang diincar oleh konsumen dengan pendidikan tinggi. Responden yang terjaring merupakan responden dengan pendidikan tinggi, disebabkan karena rata-rata mereka yang datang berkunjung ke kota Mataram dalam rangka keperluan pekerjaan seperti tugas dinas dan urusan bisnis. Mayoritas orangorang ini merupakan orang penting dalam kantor mereka sehingga mengharuskan mereka untuk memiliki pendidikan tinggi guna memimpin kantor atau perusahaan. Responden tersebut menyempatkan diri untuk meluangkan waktu mencari pernak- 


\begin{tabular}{cc}
\hline JURNAL MAGISTER MANAJEMEN \\
UNIVERSITAS MATARAM \\
UNRAM
\end{tabular}

pernik sebagai cinderamata, di saat mereka memiliki kesibukan dengan tugas dinasnya di kota Mataram ataupun di pulau Lombok.

Dari hasil pengujian validitas dan reliabilitas, terlihat bahwa alat ukur yang digunakan untuk menilai variabel produk semuanya mempunyai nilai $r$ hitung $>r$ kritis $(0,300)$. Artinya, kedelapan pernyataan yang dipakai untuk mengukur produk adalah valid. Dari hasil uji juga diperoleh nilai r Alpha Cronbach $(0,831)$ lebih besar dibandingkan dengan 0,600. Kedelapan pernyataan terkait produk toko perhiasan emas dan mutiara di Sekarbela kota Mataram dinyatakan reliable. Selanjutnya alat ukur yang digunakan untuk menilai variabel harga semuanya mempunyai nilai $r$ hitung $>\mathrm{r}$ kritis $(0,300)$. Artinya, kelima pernyataan yang dipakai untuk mengukur harga termasuk valid. Untuk hasil uji reliabilitas diketahui nilai $\mathrm{r}$ Alpha Cronbach $(0,634)$ lebih besar dibandingkan dengan 0,600 yang menyatakan bahwa kelima pernyataan terkait harga pada toko perhiasan emas dan mutiara di Sekarbela kota Mataram adalah reliable. Alat ukur yang digunakan untuk menilai variabel store atmosphere semuanya mempunyai nilai $r$ hitung $>r$ kritis $(0,300)$. Artinya, keempat pernyataan yang dipakai untuk mengukur store atmosphere adalah valid. Dari hasil uji juga diperoleh nilai $\mathrm{r}$ Alpha Cronbach $(0,741)$ lebih besar dibandingkan dengan 0,600. Keempat pernyataan terkait store atmosphere toko perhiasan emas dan muutiara di Sekarbela kota Mataram dinyatakan reliable. Sedangkan, hasil uji terhadap pernyataan-pernyataan terkait minat beli konsumen pada toko perhiasan emas dan muutiara di Sekarbela kota Mataram ditemukan nilai $r$ hitung yang juga lebih besar dari pada $r$ tabel $(0,300)$, artinya pernyataan-pernyataan tersebut valid. Dari hasil uji juga diperoleh nilai $r$ Alpha Cronbach $(0,647)$ lebih besar dibandingkan dengan 0,600. Kelima pernyataan terkait minat beli konsumen pada toko perhiasan emas dan mutiara di Sekarbela kota Mataram dinyatakan reliable.

Indikasi terjadinya multikolinieritas adalah bila batas VIF adalah 10 dan Tolerance 0,10. Jika nilai VIF lebih besar dari 10 dan Tolerance kurang dari 0,10 maka terjadi multikolinieritas. Dari analisis terlihat bahwa semua variabel independen yang terdiri dari variabel produk, harga dan store atmosphere, terbebas dari masalah multikolinieritas atau tidak ada variabel independen yang terkena multikolinieritas.

Heteroskedastatisitas tidak terjadi jika data terpencar di sekitar angka nol (0 pada sumbu Y) dan tidak membentuk suatu pola/trend garis tertentu sebagaimana terlihat pada Gambar 4. Dari gambar uji heteroskedastisitas, terlihat sebaran data ada di sekitar titik nol dan tidak tampak adanya suatu pola tertentu pada sebaran data tersebut. Maka dapat dikatakan tidak terjadi heteroskedastisitas pada data penelitian mengenai pengaruh dari variabel produk, harga dan store atmosphere terhadap minat beli konsumen pada toko emas dan mutiara di Sekarbela kota Mataram.

Uji autokorelasi dilakukan untuk memberikan jaminan bahwa residual dari responden yang berdekatan tidak sama $(e i \neq$ ej). Pengujian gejala autokorelasi dilakukan dengan uji Durbin-Watson (DW), dimana diperoleh nilai DW hitung sebesar 1,850. Oleh karena pengambilan keputusan yaitu tidak ditolak dengan kesimpulan tidak ada autokorelasi berada pada rentang 1,758 $\left(\mathrm{d}_{\mathrm{U}}\right)$ sampai dengan 
2,242 (4- $\left.\mathrm{d}_{\mathrm{U}}\right)$, maka dalam penelitian mengenai pengaruh dari variabel produk, harga dan store atmosphere terhadap minat beli konsumen pada toko emas dan mutiara di Sekarbela kota Mataram tidak terjadi autokorelasi. Jadi dalam model regresi penelitian ini dapat dikatakan sebagai model regresi yang baik, karena data dalam penelitian terbebas dari gejala autokorelasi.

Analisis regresi linier bergandadigunakan untuk mengetahui pengaruh dari variabel produk, harga dan store atmosphere terhadap minat beli konsumen pada toko emas dan mutiara di Sekarbela kota Mataram. Proses analisis regresi linier berganda tersebut menggunakan bantuan program software komputer yaitu SPSS. Berikut ini akan disajikan hasil persamaannya, yaitu:

$$
Y=2,557+0,209 X_{1}+0,159 X_{2}+0,241 X_{3}
$$

Nilai konstanta pada persamaan tersebut sebesar 2,557. Ini berarti bahwa apabila ketiga variabel bebas yang terdiri dari variabel produk, harga dan store atmosphere diasumsikan tidak ada, maka nilai dari minat beli konsumen pada toko emas dan mutiara di Sekarbela kota Mataram sebesar 2,557.

Pengaruh variabel produk $\left(\mathrm{X}_{1}\right)$ terhadap minat beli konsumen pada toko emas dan mutiara di Sekarbela kota Mataram (Y) dapat diketahui berdasarkan perhitungan dengan program SPSS, maka diperoleh nilai koefisien regresi untuk variabel produk sebesar 0,209 yang berarti bahwa untuk setiap peningkatan variabel produk, akan meningkatkan minat beli konsumen dengan asumsi variabel harga dan store atmosphere tidak mengalami perubahan, baik peningkatan maupun penurunan.

Untuk pengaruh variabel harga $\left(\mathrm{X}_{2}\right)$ terhadap minat beli konsumen pada toko emas dan mutiara di Sekarbela kota Mataram (Y), diperoleh nilai koefisien regresi sebesar 0,159. Artinya untuk setiap peningkatan variabel harga, dapat meningkatkan minat beli konsumen dengan asumsi variabel produk dan store atmosphere tidak mengalami peningkatan ataupun penurunan.

Pengaruh variabel store atmosphere $\left(\mathrm{X}_{3}\right)$ terhadap minat beli konsumen $(\mathrm{Y})$ dengan program SPSS, diperoleh nilai koefisien regresi sebesar 0,241. Artinya untuk setiap peningkatan variabel store atmosphere sebanyak 1 satuan maka akan meningkatkan minat beli konsumen sebesar 0,241 satuan dengan asumsi variabel lain tidak mengalami perubahan baik peningkatan atau penurunan. Dari hasil analisis regresi yang telah dilakukan dapat disimpulkan bahwa semakin tinggi store atmosphere maka semakin tinggi minat beli konsumen. Demikian pula sebaliknya, apabila terjadi penurunan store atmosphere maka akan ikut menurunkan minat beli konsumen pada toko emas dan mutiara di Sekarbela kota Mataram juga.

Diperoleh koefisien determinasi berganda $\left(R^{2}\right)$ yang disesuaikan sebesar 0,541 atau sebesar 54,10 persen. Hal ini berarti bahwa kontribusi dari masing-masing variabel bebas yang terdiri dari produk, harga dan store atmosphere dalam membentuk minat beli konsumen pada toko emas dan mutiara di Sekarbela kota Mataram sebesar 54,10 persen. Sisanya sebesar 45,90 persen dijelaskan oleh variabel lain yang tidak diteliti dalam penelitian ini.

Dapat diketahui $\mathrm{F}$ hitung sebesar 4,334 dengan tingkat signifikan 0,007. Sedangkan jika dibandingkan dengan $\mathrm{F}$ tabel ditentukan berdasarkan tabel dengan 


\begin{tabular}{cc}
\hline JURNAL MAGISTER MANAJEMEN \\
UNIVERSITAS MATARAM \\
UNRAM
\end{tabular}

tingkat signifikan 5 persen dan df1 $(\mathrm{k}=4)$ serta df2 $(\mathrm{n}=100)$ sehingga diperoleh nilai $F$ tabel sebesar 2,460. Dengan demikian nilai F hitung $>$ F tabel $(4,334>2,460)$. Artinya variabel bebas yang terdiri dari produk, harga dan store atmosphere memiliki pengaruh yang positif dan signifikan terhadap variabel terikat minat beli konsumen pada toko emas dan mutiara di Sekarbela kota Mataram.

Berikut ini akan diuraikan makna dari hasil analisis masing-masing variabel produk, harga dan store atmosphere yang memiliki pengaruh signifikan terhadap minat beli konsumen pada toko emas dan mutiara di Sekarbela kota Mataram. Tingkat signifikansi variabel produk $\left(\mathrm{X}_{1}\right)$ terhadap minat beli konsumen pada toko emas dan mutiara di Sekarbela kota Mataram (Y) diperoleh $t$ hitung sebesar 2,172 dengan nilai signifikan 0,035. Apabila nilai t hitung sebesar 2,172 dibandingkan dengan nilai $t$ tabel sebesar 1,984, maka nilai t hitung tersebut lebih besar dari pada $\mathrm{t}$ tabel yang berarti $\mathrm{H}_{0}$ ditolak dan $\mathrm{H}_{\mathrm{a}}$ diterima. Hal ini juga dapat dilihat dari nilai perbandingan antara nilai signifikan yang dicapai sebesar 0,035 yang berarti tingkat kesalahan lebih kecil dari 5 persen. Dengan demikian variabel produk memiliki pengaruh positif dan signifikan terhadap minat beli konsumen pada toko emas dan mutiara di Sekarbela kota Mataram.

Pengaruh variabel harga $\left(X_{2}\right)$ terhadap minat beli konsumen pada toko emas dan mutiara di Sekarbela kota Mataram (Y) diperoleh hasil t hitung untuk sebesar 2,039 dengan nilai signifikan 0,043. Apabila nilai $t$ hitung sebesar 2,039 dibandingkan dengan nilai $\mathrm{t}$ tabel sebesar 1,984, maka nilai $\mathrm{t}$ hitung tersebut lebih besar dari pada $\mathrm{t}$ tabel yang berarti $\mathrm{H}_{0}$ ditolak dan $\mathrm{H}_{\mathrm{a}}$ diterima. Hal ini juga dapat dilihat dari nilai perbandingan antara nilai signifikan yang dicapai sebesar 0,043 yang berarti tingkat kesalahan lebih kecil dari 5 persen. Dengan demikian variabel harga memiliki pengaruh positif dan signifikan terhadap minat beli konsumen pada toko emas dan mutiara di Sekarbela kota Mataram.

Untuk pengaruh variabel store atmosphere $\left(\mathrm{X}_{3}\right)$ terhadap minat beli konsumen pada toko emas dan mutiara di Sekarbela kota Mataram (Y) diperoleh hasil t hitung untuk sebesar 2,270 dengan nilai signifikan 0,025. Apabila nilai $t$ hitung sebesar 2,270 dibandingkan dengan nilai $\mathrm{t}$ tabel sebesar 1,984, maka nilai $\mathrm{t}$ hitung tersebut lebih besar dari pada $\mathrm{t}$ tabel yang berarti $\mathrm{H}_{0}$ ditolak dan $\mathrm{H}_{\mathrm{a}}$ diterima. Hal ini juga dapat dilihat dari nilai perbandingan antara nilai signifikan yang dicapai sebesar 0,025 yang berarti tingkat kesalahan lebih kecil dari 5 persen. Dengan demikian variabel store atmosphere memiliki pengaruh positif dan signifikan terhadap minat beli konsumen pada toko emas dan mutiara di Sekarbela kota Mataram.

Berdasarkan hasil analisis regresi linier berganda diketahui bahwa nilai $\mathrm{t}$ hitung yang paling besar adalah $\mathrm{t}$ hitung untuk variabel store atmosphere yaitu sebesar 2,270. Dengan demikian dapat dikatakan bahwa variabel yang dominan dalam mempengaruhi minat beli konsumen pada toko emas dan mutiara di Sekarbela kota Mataram adalah variabel store atmosphere. Hasil analisis ini sesuai dengan hipotesis yang diajukan, dimana variabel yang dominan dalam mempengaruhi minat beli konsumen pada toko emas dan mutiara di Sekarbela kota Mataram adalah variabel store atmosphere. 


\section{JMM UNRAM

\section{Kesimpulan dan Rekomendasi}

Berdasarkan penelitian yang dilakukan, ditemukan variabel produk, harga, dan store atmosphere berpengaruh positif dan signifikan terhadap minat beli konsumen pada toko perhiasan emas dan mutiara di Sekarbela kota Mataram. Hal ini ditunjukkan oleh nilai $\mathrm{F}$ hitung yang lebih besar dari $\mathrm{F}$ tabel, dan nilai $\mathrm{t}$ hitung dari masing-masing variabel bebas yang lebih besar jika dibandingkan dengan nilai $\mathrm{t}$ tabel, serta nilai signifikansi yang lebih kecil dari 5 persen. Makna dari pengaruh positif adalah semakin tinggi produk, harga, dan store atmosphere, maka semakin tinggi minat beli pada konsumen. Sebaliknya semakin rendah produk, harga, dan store atmosphere maka semakin rendah juga minat beli konsumen pada toko perhiasan emas dan mutiara di Sekarbela kota Mataram.Variabel store atmosphere merupakan variabel yang dominan mempengaruhi minat beli konsumen pada toko perhiasan emas dan mutiara di Sekarbela kota Mataram. Hal ini dibuktikan oleh hasil analisis regresi linier berganda dimana nilai $t$ hitung yang terbesar diperoleh variabel store atmosphere.

Hasil dari temuan penelitian dapat direkomendasikan beberapa implikasi kebijakan sesuai dengan prioritas yang dapat diberikan sebagai masukan bagi pihak pemilik toko perhiasan emas dan mutiara di Sekarbela kota Mataram. Disarankan kepada pemilik toko perhiasan emas dan mutiara di Sekarbela kota Mataram agar tetap mempertahankan harga yang telah berlaku selama ini dan tidak mengambil keuntungan yang terlalu tinggi dari biaya produksi yang dikeluarkan.Pihak pemilik toko perhiasan emas dan mutiara di Sekarbela kota Mataram juga diharapkan selalu memperhatikan atas kelengkapan produk yang ditawarkan, sebagai usaha memberikan jaminan bahwa konsumen dapat mendapatkan produk sesuai yang dibutuhkan.

\section{Daftar Pustaka}

Berman, B. dan Evans, J.R., (2001), Retail Management: a Strategic Approach (8thed.) Upper Saddle River: Pretice Hall International, Inc. (2004), Retailing Management and Strategic Approach (9thed). New Jersey: Prentice Hall.

Kotler, P., (2006), Manajemen Pemasaran, jilid I, Edisi kesebelas, Jakarta: Indeks Gramedia. ,(2006), Manajemen Pemasaran, jilid II, Edisi kesebelas, Jakarta: Indeks Gramedia.

Lamb, W.,Hair, McDaniel, dan Carl, (2001), Pemasaran, Buku Satu, Edisi Pertama, Jakarta: Salemba Empat.

Malhotra, N.K., (2007), Marketing Research an Applied Orientation, New Jersey: Prentice Hall.

Peter, J.P. dan Olson, J.C., (2001), Consumer Behavior: Perilaku Konsumen dan Strategi Pemasaran, Jakarta: Erlangga.

Sekaran, U., (2006), Metode Penelitian Bisnis, Jakarta: Salemba Empat.

www.logammulia.com diakses tanggal 12 Juli 2014. 